https://helda.helsinki.fi

From narcissism to face work : two views on the self in social interaction

Peräkylä, Anssi Matti

2015-09-30

Peräkylä , A M 2015 , ' From narcissism to face work : two views on the self in social interaction ' , American Journal of Sociology , vol. 121 , no. 2 , pp. 445 . https://doi.org/10.1086/682282

http://hdl.handle.net/10138/233967

https://doi.org/10.1086/682282

publishedVersion

Downloaded from Helda, University of Helsinki institutional repository.

This is an electronic reprint of the original article.

This reprint may differ from the original in pagination and typographic detail.

Please cite the original version. 


\title{
From Narcissism to Face Work: Two Views on the Self in Social Interaction ${ }^{1}$
}

\author{
Anssi Peräkylä \\ University of Helsinki
}

\begin{abstract}
Through the analysis of conversational interaction and clinical notes, this article develops conceptual linkages between the Goffmanian concept of face and the psychoanalytic and psychiatric understandings of narcissism. Self-cathexis - the investment of libidinal emotion to the image of self-is a key issue both for Goffman and in psychoanalytic studies of narcissism. For Goffman, the self and its cathexis are inherently fragile interactional achievements, whereas for psychoanalysts such as Kernberg and Kohut, they are relatively stable intrapsychic structures. An application of Goffman's theory to narcissistic personality disorders suggests that pathological narcissism involves the isolation of the person's self-image from interactional practices and a consequent inability to benefit from face work in ordinary social encounters. Clinical experience suggests revisions to the theory of face work: there is a biographical continuity in a person's experience of face, and successful participation in face work is made possible by the psychic capacity of playful orientation to one's own and others' narcissistic illusions. Such playful orientation is manifested through the interactional practices of role distancing.
\end{abstract}

The place of psychological considerations - of individual personality, motivations, and emotions-in Erving Goffman's interactional theory remains unclear and disputed. Goffman himself was ambiguous. In the introduction

${ }^{1}$ I wish to thank Elizabeth Couper-Kuhlen, Henrik Enckell, Auli Hakulinen, John Heritage, Mikael Leiman, Ivan Leudar, Johanna Ruusuvuori, Ulrich Streeck, and Liisa Voutilainen for useful suggestions regarding this manuscript, as well as the $A J S$ reviewers for numerous helpful comments. I also want to thank Seppo Randell, to whom I dedicate this article to celebrate his 81st birthday. Direct correspondence to Anssi

(C) 2015 by The University of Chicago. All rights reserved.

0002-9602/2015/12102-0003\$10.00

AJS Volume 121 Number 2 (September 2015): 445-74

445 
to Interaction Ritual, he pointed out that "the proper study of interaction is not the individual and his psychology, but rather the syntactical relations among the acts of different persons" (Goffman 1967, p. 2). However, he also maintained that in the study of interaction, a model of "general properties" of individual actors is needed. But while "psychology is necessarily involved," it is psychology of a particular kind: "one stripped and cramped to suit the sociological study of conversation, track meets, banquets, jury trials, and street loitering” (p. 3; see also, e.g., Goffman 1956, pp. 269-70).

While Goffman was inexplicit about the content and the place of this "stripped and cramped" psychology, his commentators have seen it in quite different ways. Thus, Schegloff (1988) criticized Goffman for being analytically imprisoned by his engagement with the psychology of individual actors: Goffman's "perduring entanglement with 'ritual' and 'face' kept him in the psychology" (p. 94). This impeded Goffman from the investigation of "syntactical relations between acts" in their own right. Lerner (1996) saw Goffman's engagement with self and face differently, arguing that an adequate analysis of face (and, hence, of the psychological aspects of interaction) could be brought about by the very procedure that Schegloff saw as impeded by Goffman's engagement with psychology: by examining the syntactic relations between acts. In Lerner's eyes, the features of individual psychology, for example, feelings attached to self, are produced through "courses of action in interaction." Lerner investigated a particular course of action, anticipatory completion of a coconversationalist's utterances, as a means of avoiding disagreement and the problems with face that it entails. The description of courses of action constitutive of face and self has been extended by Maynard and Zimmerman (1984) and Heritage and Raymond (2005).

In this article, I take up the psychology of individual actors in interaction. I do this by exploring linkages between a Goffmanian analysis of interaction and psychoanalytic psychology-thereby engaging with psychology more than earlier commentators on Goffman have done. The meeting point between psychology and the study of interaction is in Goffman's concept of face, denoting the positive value of self, which I argue encapsulates some of the phenomena that in psychoanalytic psychology and contemporary psychiatry are referred to as narcissism. I argue that Goffmanian theorizing about face can benefit from an engagement with psychoanalytic and psychiatric understandings of narcissism and that psychoanalytic theory regarding narcissism can benefit from an engagement with a Goffmanian theory of face.

In the text that follows, three different perspectives on the relationship between Goffman's concept of face and a psychoanalytic understanding of

Peräkylä, Center of Excellence on Intersubjectivity in Interaction, University of Helsinki, Post Office Box 4, 00014 University of Helsinki, Helsinki, Finland. E-mail: anssi. perakyla@helsinki.fi 
narcissism are intermingled. In a historical perspective, I suggest that there is a connection in the emergence of these two lines of research on self that has so far been neglected. In a contrastive perspective, I highlight the basic differences regarding the constitution of self between Goffmanian and psychoanalytic lines of research. In a constructive perspective, I show ways in which the two understandings of self can still mutually elaborate each other. The main import of the article lies in the contrastive and the constructive perspectives, rather than in the historical one.

While the primary thrust of this article is theoretical, two sorts of empirical materials are included by way of elaborating and concretizing the theoretical argument: a fragment of ordinary conversation and excerpts from clinical notes stemming from the psychoanalytic treatment of a patient with fragile self-experience.

The line of research that has emerged from Goffman's work is vast and divergent, and that emerging in the psychoanalytic tradition is even more so. In discussing Goffman, my anchor point is mostly the conversation analytical lineage arising from his seminal work. In discussing psychoanalytic conceptions of self, I start by engaging with Otto Kernberg's and especially Heinz Kohut's influential theories of narcissism. When discussing the possibility of mutual elaboration between Goffman and psychoanalysis, I will move my anchor point to the more recent tradition of relational psychoanalysis. Many important psychoanalytic conceptualizations of narcissism, such as those by Stolorow (1975), Etchegoyen (1985), and Green (2002), go beyond the scope of this article.

\section{A NEGLECTED CONNECTION}

A short passage in Goffman's famous essay On Face Work (Goffman [1955] 1967 , p. 6) catches the eye: "A person tends to experience an immediate emotional response to the face a contact with others allows him; he cathects his face; his 'feelings' become attached to it." What Goffman calls face is the positive social value a person claims for himself in interaction, a value that the cointeractants ratify. But what does it mean for a person to cathect his face?

The noun cathexis, from which the verb to cathect is derived, comes from James Strachey, the English translator of Freud. In referring to the investment of libidinal energy to objects, Freud used the term Besetzung. The original meaning of the German word is something like "casting" or "occupation." Here, as elsewhere, Strachey chose words of Greek origin instead of, like Freud, using everyday terms. So Besetzung became cathexis, derived from the Greek word $\kappa \dot{\alpha} \theta \xi \iota \varsigma$, which means holding or retention. Cathexis became the English language psychoanalytic word for referring to the investment of mental energy to objects. 
Parsons and Shils (Parsons 195 1; Parsons and Shils 1951, pp. 68-69) took up the Freudian idea in their social theory, pointing out that for an actor in a social system, the other actors (as well as physical or cultural entities) can be "objects of cathexis" (p. 55). The cathexis of objects brings "energy or motivation" into the social system (pp. 59 n. 5, pp. 68-69). Cathectic orientation to a situation is constitutive for the actor's motivation, alongside cognitive and evaluative orientations (Parsons 1951, e.g., p. 7). So, cathexis as an idea was present in American sociological theory at the time when Goffman was writing his essay on face work. However, a shift occurred in Goffman's usage of this notion: the aspect of cathexis that he addressed was linked not to other actors but to the person him- or herself. Here, Goffman appears to be following the train of thought initiated by Heinz Hartmann.

In a text published in 1950 - five years before Goffman's On Face WorkHeinz Hartmann, who was a leading proponent of American ego psychology, formulated an idea of self-cathexis (Hartmann [1950] 1964). Hartmann was echoing and elaborating Freud's ([1914] 1957, p. 75) idea of the "original libidinal cathexis of the ego," that is, a child's primary love of herself, from which the love directed to other people is later given off. Not only other people or ideas can receive cathexis, but also the person him- or herself can become cathected. "The opposite of object cathexis is . . cathexis of one's own person, that is, self-cathexis." While also discussing the conceptual difference between ego and self in ways that are not directly relevant for this article, Hartmann proceeds to define narcissism through the idea of selfcathexis: "We define narcissism as the libidinal cathexis . . . of the self" (Hartmann 1964, p. 127). Hartmann's idea was soon picked up by the two perhaps most influential psychoanalytic theorists of narcissism in the decades to come, Otto Kernberg and Heinz Kohut, who, in spite of their deep disagreements (see Ornstein 1991), shared the idea of self-cathexis.

So in 1955, when On Face Work was published, the term self-cathexis was present. Goffman will have been well aware of his choice of words. Substituting the unspecific concept of "feelings" to the psychoanalytic idea of "libido," he paraphrased his key idea very much the same way as the psychoanalyst of the time paraphrased self-cathexis, as he wrote that "what the person ... invests his feelings in is an idea about himself" (Goffman 1967, p. 43). For Goffman, self-cathexis involves investment of feelings in self. Kernberg, in his paraphrase of self-cathexis, was to use almost the same wording in 1975: "I define normal narcissism as the libidinal investment of the self" (1975, p. 315).

If some of the key terms in Goffman's theory of face and the psychoanalytic theory of narcissism are almost the same, what can be said about the key ideas? In what follows, I compare Goffmanian and psychoanalytic understandings of face, narcissism, and self-cathexis in three rounds: first, trying to bring out their deep differences in understanding what psychoanalysts might 
call normal narcissism, second, laying out points of connection by using clinical case material on narcissistic disorder, and third, discussing the Goffmanian implications of some more recent ways of thinking about therapy for narcissistic disorders.

Let us, however, start with a data extract derived from ordinary interaction. This segment, examined here using conversation analytical methods (Sidnell 2012), will give us an initial understanding of the phenomenon to be investigated.

\section{BEING A HEDONISTIC EATER}

Two middle-aged sisters, Jaana and Tuula, are having coffee at Tuula's house. Earlier during the encounter, they were talking about honey. Right before the conversation fragment shown in extract 1 (fig. 1), Tuula told her sister about a friend of hers, a professional in food who adds sugar in many kinds of dishes, making them taste better. Jaana now, from line 1 onward, returns to the benefits of honey. The text of the transcript is presented in paired lines: above, there is the Finnish original, and below, an idiomatic English translation (for transcription symbols, see the appendix).

At the beginning of this fragment, in lines 1-12, the participants reach agreement on the good qualities of honey. In lines 1 and 2, Jaana starts an assessment regarding honey, notably heading toward saying that honey has benefits beyond those of sugar. Jaana's utterance here is slightly disaffiliative in relation to Tuula's earlier appreciative story about the friend who uses sugar in cooking (not shown in the data). The contrast between honey and sugar is embodied in the turn-initiating "but" (line 1) and in the emphasis on "honey" in line 2. An agreement regarding honey is nevertheless achieved, and several rounds of accounts and confirmations ensue. So, in lines 05, 09, and 12, Tuula completes and elaborates the assessment of honey, as compared to sugar. Jaana receives the completion and expansions by agreeing in lines 08, 11, and 13.

Now Jaana, in lines 13 and 14, adds another facet to the assessment: honey is also healthier. Through her lexical choices and prosody, she, however, gradually backs down from her assessment during its production. She starts by marking the assessment as a subjective one ("in my opinion"). Different kinds of qualification follow, marking the perspective as someone else's ("it's . . . supposed to be") and the statement as epistemically questionable ("as if"). Jaana's voice becomes quieter on the word "healthier" (at a point when her gaze reaches Tuula's gaze); the voice quality conveys hesitation or uncertainty.

Throughout her utterance, Jaana thus increasingly orients to Tuula's anticipated disaffiliation or disagreement. Even though Tuula does not indicate her disagreement verbally at this point, her face and posture seem to 


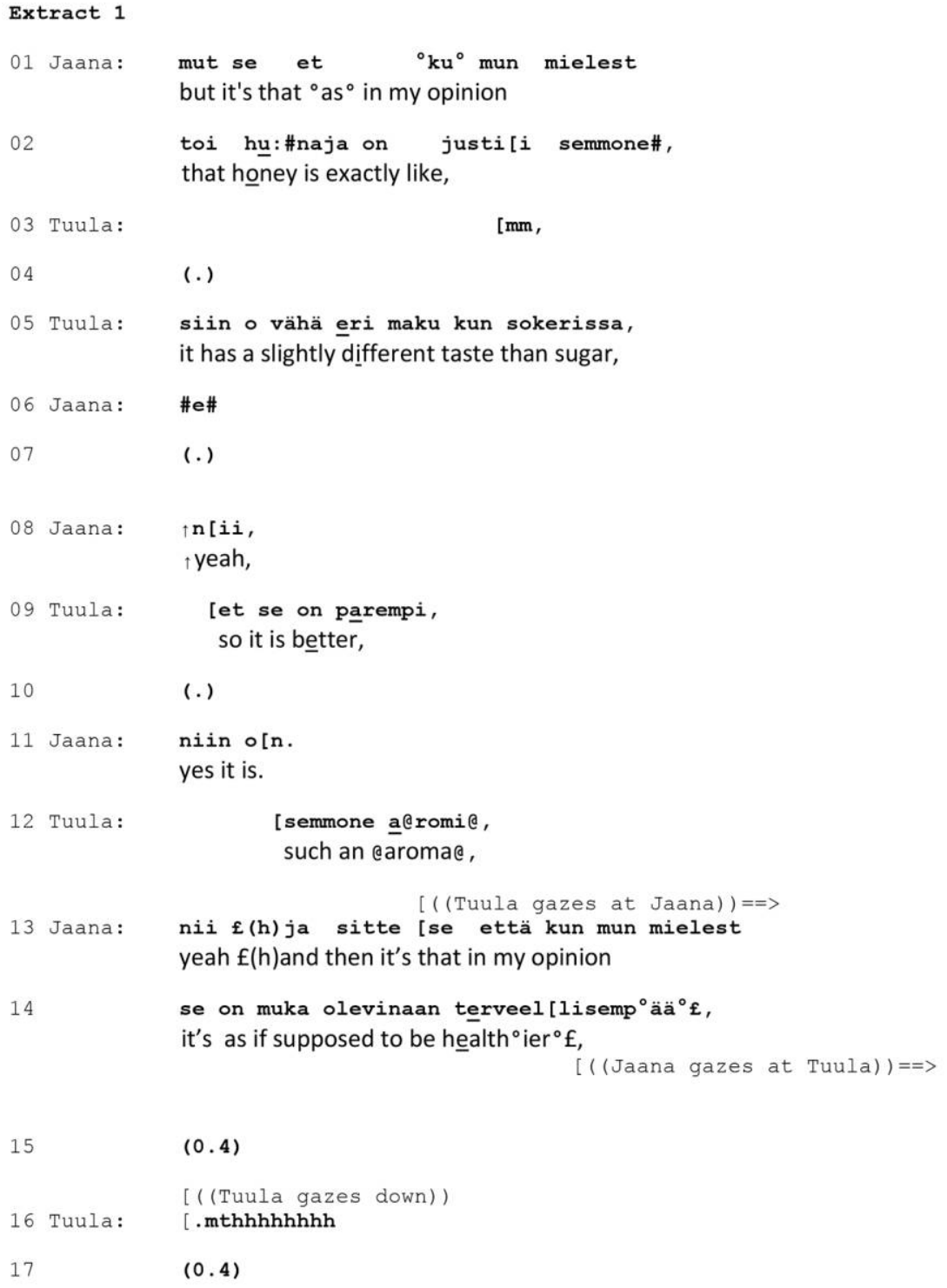

FIG. 1.-Extract 1, Tuula and Jaana 
18 Jaana: tsh mukam[as,

tch supposiedly,

19 Tuula: [m:ä en koskaan [aattele

[I: never [think about

[( (Jaana gazes down))

20

mitää [n ter ] veysasioita

any health issues

21 Jaana:

[.nff ]

22 Tuula:

kun mä 1- (.) laitan ruokaa tai sy:ön?

when I m- (.) make food or ea:t?

$(0.2)$

24 Jaana: .mth [h no ( - )

25 Tuula:

[>se pitää [olla<

[it has to

[taste<

] hỵvää ;

[no (kyl mä-)]

[well (I surely)

27

$(0.2)$

28 Jaana:

jooh. .hh mut katos se että ku, (.)

yes. .hh but see, it's that (.)

29

.hh mä käytän; (.) \#ä\# ruuanlaitos oikeeta \voita? .hh I use (.) erm in cooking real $\downarrow$ butter?

30

$(0.2)$

31 Tuula:

$\mathrm{m} \downarrow \mathrm{m}$ ? (.) niin mä ${ }^{\circ} \mathrm{ki}\left[\mathrm{h}^{\circ}\right.$.

$\mathrm{mm}(.) \mathrm{me}^{\circ} \mathrm{too}^{\circ}$.

32 Jaana:

[ja sit[te nii, (.) hunajaa, and then (.) honey,

33 Tuula:

[aina.

always.

FIG. 1.-(Continued $)$ 
suggest as much: she looks at Jaana with her chin up, with a neutral face, as shown in figure $2 A .^{2}$ After the point of completion in line 14, a silence follows. Tuula breaths in and withdraws from her postural orientation toward Jaana (lines 15-17; fig. 2B). Jaana smiles, gazing at Tuula (fig. 2B).

In line 18, Jaana adds, as an increment (Schegloff 1996) to her already completed utterance, another reservation to her assessment, by reexpressing her doubt (mukamas/supposedly). Just before the word, she snorts, withdraws her gaze from Tuula, and then, while talking, tilts her head and looks at Tuula, as it were, from below (see fig. $2 C$ ). This creates the impression of being apologetic or appealing — but in a light and humorous way.

Up to this point, Tuula's disaffiliation has been conveyed only through nonverbal means (see fig. 2A), while Jaana has been orienting herself to it in her utterance design and nonverbal comportment. In lines 19, 20, 22, and 25, however, Tuula openly disaffiliates with Jaana. Rather than producing the relevant next action (second assessment regarding honey), Tuula openly challenges Jaana by claiming her disinterest in health issues. In doing so, she refutes the relevance of Jaana's preceding assessment. Through an extreme case formulation (Pomeranz 1986; en koskaan/never, mitään/any), she distances herself from Jaana's health concerns in lines 19 and 20 and describes her own appreciation of good taste in contrast (line 25). Through this Tuula presents herself as a hedonist rather than as a health-oriented person.

In lines 28, 29, and 32, Jaana offers a parallel account of her cooking habits, claiming in essence that her habits are hedonistic also (using "real butter" and honey). The account of cooking habits becomes competitive, as Tuula points out that she also, always, uses real butter (lines 31 and 33).

In his 1955 essay, Goffman defined face as follows: "The term face may be defined as the positive social value a person effectively claims for himself by the line others assume he has taken during a particular contact. Face is an image of self delineated in terms of approved social attributes" (1967, p. 5 ). Face is, thus, a positive image of self that a person claims for him- or herself, an image of self that gets its ratification from the person's interaction partners. In the fragment above, Tuula, and after her Jaana, treat hedonistic eating as a "positive social value" constituting an "image of self delineated in terms of approved social attributes." It is also notable that Tuula withdraws her support from an image of self that Jaana has implied in her earlier utterance - the image of herself as a health-conscious person.

Face concerns in this fragment thus reach the surface of interaction. With her disaffiliative account of her cooking habits beginning in line 19,

\footnotetext{
${ }^{2}$ Alongside Tuula's nonverbal expression, knowledge shared by the participants, regarding their respective views on food and health, may be involved in Jaana's anticipation of disagreement, but the data do not give us access to that. On speakers monitoring visual recipient action, see Goodwin (1980).
} 

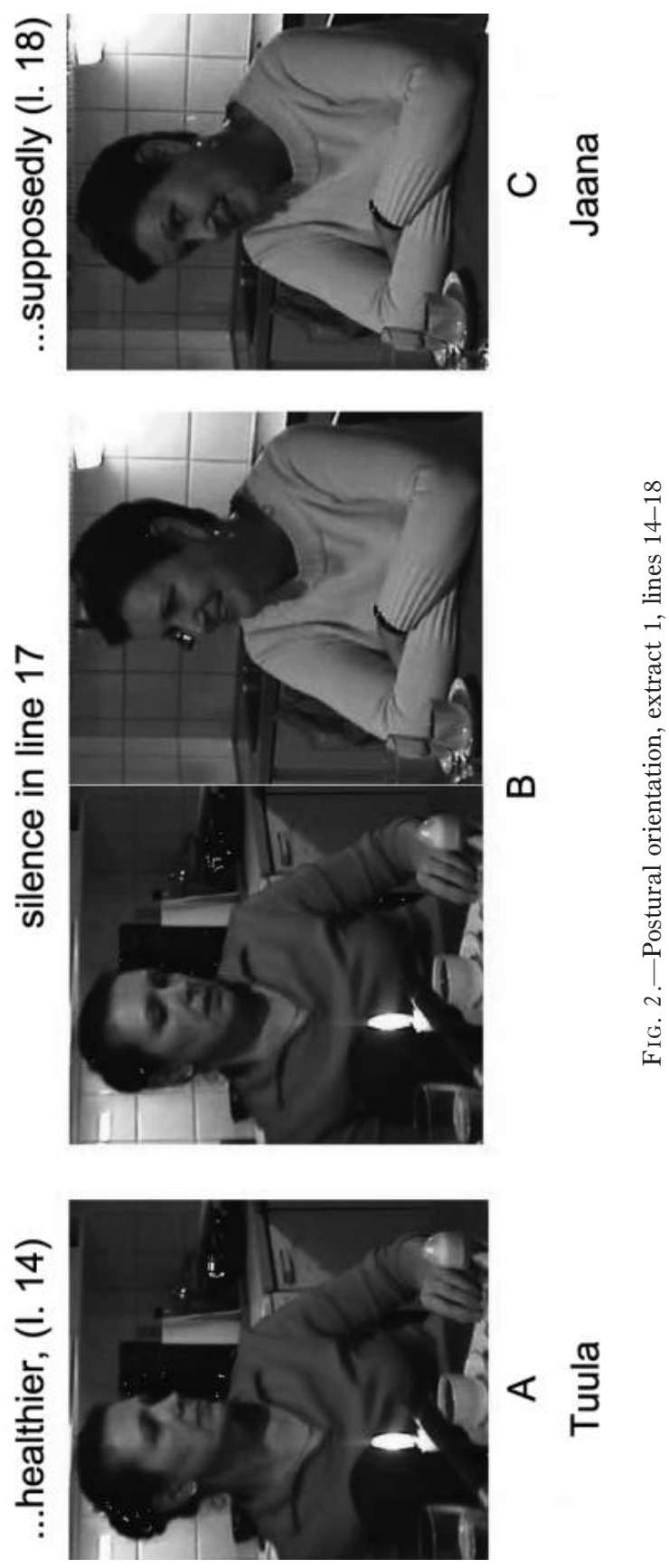

This content downloaded from 128.214.210.087 on April 06, 2018 02:55:40 AM All use subject to University of Chicago Press Terms and Conditions (http://www.journals.uchicago.edu/t-and-c). 
Tuula puts a "face threatening act" on record, without redress (see Brown and Levinson 1987).

\section{THREE COMPARISONS}

\section{Social and Internal Self}

In this section, I contrast Goffman's views of self with those of narcissism held by two leading psychoanalysts. Otto Kernberg's and Heinz Kohut's first writings on narcissism originated in the early 1960s. Despite their divergent accounts, they remain key theorists on the field. I will argue that while both Goffman and the psychoanalysts are concerned with a person's ideas, images, and representations regarding him- or herself, for Goffman, the self is primarily dependent on situational interaction, while for Kernberg and Kohut, it is anchored in the psychic structure shaped in individual development.

Both Kernberg and Kohut understand the self as an intrapsychic structure. For Kernberg, it consists of "multiple self representations and their related affect dispositions" (1975, p. 315). These representations reflect "the person's perception of himself in real interactions with significant others and in fantasied interactions with internal representations of significant others" (pp. 315-16). The degree to which the self receives libidinal investment (resulting in good self-esteem or self-regard) is a consequence of biographical experience and the internal dynamics of the mind - of ego ideals, superego factors, representations of others, as well as love received from others, gratifications, achievements, and the person's physical health (pp. 318-20; see also Kernberg 1991). In healthy development, libidinal investment of the self (selfcathexis) and libidinal investment of others (object cathexis) are separate but mutually reinforcing; furthermore, libidinal investments and aggressive investments are integrated. Thus, biographical experience shapes the self and its cathexis, but the self so shaped is a structure within the individual.

Kohut, while in many ways disagreeing with Kernberg, shared with him a view of the self as "a structure within the mind" (Kohut 1971, p. xv; see also Ornstein 1991). According to Kohut, in healthy infancy the child, in response to inevitable frustrations, assumes a grandiose image of self (alongside its counterpart, the image of an idealized parent object), in an attempt "to save the originally all-embracing narcissism by concentrating perfection and power upon the self" (1971, p. 106). Under favorable developmental circumstances, the archaic grandiose self of childhood gives way to more mature forms of narcissism characterized by stable self-esteem regulation (Ornstein 1991). Importantly, however, within realistic self-esteem regulation, there remain "infused" traces of the early grandiose self, fueling the individual's self-regard and persistence (Kohut 1971, p. 108). Thus, the grandiose self is not given up but modified and integrated with the rest of the psychic apparatus involving a more realistic conception of the self. 
For Kernberg and Kohut alike, the self is then an intrapsychic structure. Cathexis of the self arises from a lifelong developmental path that is shaped by the individual's real interactions with, and internalized images of, her important fellowmen. While Kernberg and Kohut understand the key challenges along this path in different ways (Kernberg emphasizing the integration of aggression and libido, Kohut emphasizing the integration of the archaic grandiose self and realistic parts of the ego), they still share an overall perspective on self-cathexis: while it inevitably involves momentary fluctuations arising from current experiences with others, it is primarily an outcome of a lifelong developmental path.

Goffman's understanding of face shares something with Kernberg's and Kohut's conceptualizations yet is quite different. What Goffman and the psychoanalysts have in common is a focus on self-representations. Goffman refers repeatedly to the "idea" or "image" of self as the core of what he calls face: "face is an image of self delineated in terms of approved social attributes" (1967, p. 5; italics added), and "what the person protects and defends and invests his feelings in is an idea about himself" (p. 43; italics added). We might say that what Goffman is referring to here is similar to what Kernberg and Kohut refer to when talking about self-representations and self-images.

However, while for Kernberg and Kohut the images/ideas/representations/perceptions of self make up an intrapsychic structure, for Goffman they inhabit the world of interaction out there. Thus, for Goffman, a person's face "is not lodged in or on his body, but rather something that is diffusely located in the flow of events in the encounter" (1967, p. 7): Goffman's "self" is inherently situational and intersubjective, produced and ratified (or not ratified) in social encounters. ${ }^{3}$

Considering the theoretical background of Goffman's idea of face and self-cathexis may help us to see more clearly his original contribution, also in relation to psychoanalysis. At the time that Goffman published his essay, the idea of self as being embedded in social interaction was by no means new. Each in different ways, William James (1891; see also Leudar and Thomas 2000, pp. 91-98), George Herbert Mead (1934; see also Joas 1985,

${ }^{3}$ Goffman is not (here or elsewhere) very clear or systematic in his use of concepts. Even though he offers definitions for "face" (see above) and "self" (Goffman 1967, p. 31), he does not clarify the distinction between the two and actually uses the two concepts almost interchangeably. We might say that "self" refers to a person's own experience of himself and others' experience of him or her more broadly, while "face" refers to the evaluative aspect of that experience. Both self and face are inherently embedded in, and produced by, social interaction. Occasionally, Goffman talks about social face or social self: analytically, this does not seem to add anything to his concepts of face and self, but rather, the attribute "social" serves as a reminder of the social origin of face and self. Here, Goffman's vocabulary is different from James's (1891), as for the latter, the social self was an aspect of the empirical self distinctly different from its two other aspects (the material self and the spiritual self). 
pp. 105-20), and Charles Horton Cooley (1902) all pointed out that what the individual experiences and perceives as himself arises from the way in which he understands that others, in different social contexts, see him and recognize him. Especially, James emphasized (as Goffman was to do more than 60 years after him), the emotional and evaluative ramifications of the social self. A lengthy citation from the Principles of Psychology illustrates how deeply Goffman is indebted to James.

A man's social self is the recognition which he gets from his mates. We are not only gregarious animals, liking to be in sight of our fellows, but we have an innate propensity to get ourselves noticed, and noticed favorably, by our kind. No more fiendish punishment could be devised, were such a thing physically possible, than that one should be turned loose in society and remain absolutely unnoticed by all the members thereof. If no one turned round when we entered, answered when we spoke, but if every person we met 'cut us dead' and acted as if we were non-existing things, a kind of rage and impotent despair would ere long well up in us, from which the cruellest bodily tortures would be a relief; for these would make us feel that, however bad might be our plight, we had not sunk to such a depth as to be unworthy of attention at all. (James 1891, pp. 293-94)

Interestingly, Goffman does not refer to James, or Cooley, or Mead, in his text on face. While the novelty of Goffman's work was thus not in showing the social origins of the self, or in pointing out the immense emotional ramifications that recognition from and by others has, it was he who powerfully illustrated the fragility and precariousness of the social self. The self, once formed in a social process, is not a stable construct but something inherently at risk due to nonrecognition or misrecognition. It is a precious possession that needs constant vigilance; the Goffmanian "individual is never secure in an encounter" (Rawls 1987, p. 140).

Consider again extract 1 . The ubiquitous insecurity of the participants is embodied not only in the assessment sequences (first in lines 1-12 and then beginning in line 13) in which the first speaker runs the risk of the other rejecting her views and not only in the competitive self-descriptions (lines 19-33) but, equally, in the very taking of turns and the production of utterances, whereby each participant claims being worthy for the other's attention (Goffman 1967, pp. 9-10).

For Goffman, the social constitution of self was not primarily an analyst's notion but a "members' concern" (on analysts' and members' concepts, see Garfinkel 1967): something that persons in interaction incessantly attend to. Furthermore, the Goffmanian actor is concerned not only about his or her own face but also about the cointeractant's face. Embarrassment, resulting from the discrepancy between the projected acceptable self and what transpires in interaction, is typically shared by those in presence, "in ever widening circles of discomfiture" (Goffman 1956, p. 268). The anxiety for one's own and the other's self penetrates interaction: "By repeatedly and auto- 
matically ${ }^{4}$ asking himself the question, 'If I do or do not act in this way, will I or others lose face?' he decides at each moment, consciously or unconsciously, how to behave" (Goffman 1967, p. 36; see also Brown and Levinson 1987, p. 61).

The momentary fragility of the Goffmanian actor's self is something that separates Goffman from the psychoanalytic theorists of narcissism we have been reviewing. The Kernbergian and Kohutian self as an intrapsychic structure is something relatively stable: while self-esteem fluctuates in response to gratifications, acceptance, and rejections received from others (Kernberg 2010, pp. 257-58), the self and its cathexis are still shaped in biographical time. The fragility of the Goffmanian self manifests itself more radically and in a much shorter time span: in the moment-by-moment time of social interaction. ${ }^{5}$

So in the psychoanalytic theories under review here, self-experience is embedded in psychic structure, while in Goffman, the self is momentary and situational. However, the momentary Goffmanian self is not without structural embeddedness-but for Goffman, the relevant structures are interactional. "One finds evidence to suggest a functional relationship between the structure of the self and the structure of spoken interaction" (Goffman 1967, p. 36). Unpacking this functional relationship, Rawls (1987, esp., pp. 137-39) suggests that the ultimate dependency of the self on social interaction places a fundamental constraint on social interaction, resulting in the independency of interaction as an ordered domain of action, separate from larger institutional structures (see also Goffman 1983). Thus, for Goffman, the existential dependency of the self on social interaction produces a two-way relation, where the self organizes social interaction, and social interaction organizes the self.

Brown and Levinson's (1987, pp. 65-68) theoretical work on politeness unpacks this further, suggesting that a multitude of conversational actionsincluding, among many others, orders, requests, suggestions, advice, reminders, compliments, criticism, disagreements (for a disagreement, see extract 1 above), news deliveries - involve what Brown and Levinson call an intrinsic face threat to the recipient or the speaker. In performing these ac-

\footnotetext{
${ }^{4}$ The word "automatically" that Goffman uses here raises a question about the consciousness attached to the considerations of face. In terms of Freud's ([1915] 1957) topographic theory, they seem to be preconscious: unconscious in a descriptive sense but readily retrievable to consciousness, as they are not subject to repression.

${ }^{5}$ Within the psychoanalytic tradition, it is Erik Erikson who has come closest to a Goffmanian understanding of the momentary fragility of self. While Erikson is usually not regarded as a theorist of narcissism, in his discussion of ego identity, he formulates the process of "communication on the ego level" in terms that come close to Goffmanian concerns about the dependency of self on social interaction. In such communication, "each ego tests all the information received sensorily and sensually, linguistically and subliminally for the confirmation or negation of its identity" (Erikson 1968, p. 220).
} 
tions (and many others), social actors have to consider the images of self that their actions project for the actor and for the recipients. Conversation analytic studies have elaborated some of these practices further, showing how participants are oriented to concerns of face in choosing topics (Maynard and Zimmerman 1984), in displaying their knowledgeability in assessments (Heritage and Raymond 2005; for face-related epistemic work in an assessment, see also lines 13,14 , and 18 in extract 1, fig. 1), and in anticipatory completion of an utterance initiated by a cointeractant (Lerner 1996). There is no reason to think that the studies thus far have exhausted the interactional practices and structures that are functionally related to concerns of face.

The notion of self-cathexis is a link between Goffman and psychoanalytic theorists of narcissism. But their understandings of the ways in which self-cathexis is molded are different. The differences are encapsulated in figure 3. For Otto Kernberg and Heinz Kohut the organization of cathexis of the self arises from individual development, which is shaped by early object relations as well as by the internal dynamics of the person. Nurturing or traumatizing interactions between a developing person and his or her most important others facilitate or fail to facilitate the development of normal narcissism. In adulthood, when the individual is equipped with mature structures of self and self-cathexis, the ups and downs of interactional relations with others result in phasic fluctuations of self-esteem.

Goffman's view of the dependence of self on interaction is different. For him, cathexis of the self arises from real time social encounters: face, or a person's image of self, emerges from encounters, and it is ratified, or fails

\begin{tabular}{|l|l|l|}
\hline & Kernberg\&Kohut & \multicolumn{1}{|c|}{ Goffman } \\
\hline $\begin{array}{l}\text { Substrate of the } \\
\text { self-cathexis }\end{array}$ & $\begin{array}{l}\text { Biographical } \\
\text { experience }\end{array}$ & $\begin{array}{l}\text { Situational } \\
\text { experience }\end{array}$ \\
\hline $\begin{array}{l}\text { Durability of the } \\
\text { self-cathexis }\end{array}$ & $\begin{array}{l}\text { Relatively } \\
\text { stable }\end{array}$ & $\begin{array}{l}\text { Momentarily } \\
\text { fragile }\end{array}$ \\
\hline $\begin{array}{l}\text { Structural } \\
\text { anchoring of the } \\
\text { self-cathexis }\end{array}$ & $\begin{array}{l}\text { In the psychic } \\
\text { structure }\end{array}$ & $\begin{array}{l}\text { In the } \\
\text { interactional } \\
\text { structure }\end{array}$ \\
\hline
\end{tabular}

FIG. 3.- Key differences in the notion of self-cathexis in Goffman and in two psychoanalytic theorists 
to be ratified, by copresent others. The maintenance of face is a reciprocal process - my face is dependent on yours, and I work to maintain your face as well as my own. Rather than being embedded in psychic structure, the Goffmanian self is embedded in the organization of social interaction. Therefore, Goffman can depict the social basis of cathexis of the self in this, we might say, sober way: "while [a person's] social face can be his most personal possession and the centre of his security and pleasure, it is only a loan to him from society" (1967, p. 10).

Thus, in both Goffmanian theory and in psychoanalysis (Kernberg and Kohut), social interaction is involved in self-cathexis. The key difference concerns the temporality of the relevant interaction-whether it is seen in biographical time (as in psychoanalysis) or in the moment-by-moment time of a single encounter (as in Goffman). In both views, the self and its cathexis are embedded in structures that have persistence over time. For Goffman, such structures involve the organization of social interaction, while for psychoanalysts, the relevant structures concern the enduring organization of mind.

In the next sections, I discuss a possible rapprochement between these views; such a rapprochement could lead to fruitful expansions and revisions in both views. Narcissistic personality disorder provides the empirical context for this discussion.

\section{Face and Pathological Narcissism}

So far, I have been speaking about "ordinary" narcissistic phenomena: the cathexis of self that typically developed individuals have. Now, I turn to individuals whose cathexis of self is somehow different. Through considering what in psychiatry is called pathological narcissism (e.g., Pincus and Roche 2011) or, in a more narrow and diagnostic sense, narcissistic personality disorder (Ronningstam 2012; APA 2013), I will add a new layer to the comparison between Goffman and psychoanalytic theories of narcissism.

Psychotherapeutic and psychiatric texts depict the key features of pathological narcissism and narcissistic personality disorder in rather consistent ways. The clinical picture involves a grandiose image of self and, paradoxically, an endless need to receive acceptance and love (Kohut 1971; Kernberg 1975; APA 2013). There are thus two facets in pathological narcissism: grandiosity (also referred to as overt, oblivious, or thick-skinned narcissism) and vulnerability (covert, hypervigilant, or thin-skinned narcissism; Rosenfeld 1987; Akhtar 1989; Gabbard 1989; Wink 1991; Pincus and Roche 2011). Importantly, the same persons often oscillate between grandiose and vulnerable self-states (e.g., Pincus and Roche 2011). Even though the image of self is at the heart of pathological narcissism, it also has implications for a person's relations to others: persons with narcissistic 
difficulties have a tendency to idealize some people, trying to identify with them, while they disparage others "from whom they do not expect anything" (Kernberg 1975, p. 228). Furthermore, pathological narcissism can be characterized by a lack of empathy (APA 2013).

In their dependence on approval and attention (Kohut 1971, p. 17) and in their great need to be loved and admired (Kernberg 1975, p. 227), persons with narcissistic disorder appear, at first sight, to be strikingly Goffmanian actors. A Goffmanian actor's image of self is utterly dependent on the recognition given by others. So, does the Goffmanian actor suffer what psychiatrists might call a narcissistic personality disorder? ${ }^{6} \mathrm{In}$ what follows, I argue differently, suggesting that narcissistic personality disorder is a meaningful concept, as a description of a specific atypical way of relating to oneself, also in the light of Goffman's theory of face. I present my suggestions with the help of case material from my psychotherapeutic practice. In the light of this clinical material, I also suggest some modifications to the Goffmanian concept of face.

The significance of psychoanalytic case notes as data for social research is debatable. Psychoanalytic sessions constitute a particular kind of qualitative interview (Kvale 1999, 2003), one in which formal constraints directing interviewee talk are minimized and in which the interviewee's understandings change over time. The psychoanalytic interview is meant to accommodate topics that are painful and emotional and to bring forward the patient's tacit, presuppositional knowledge about self and others (cf. Stern et al. 1998). However, psychoanalytic interviews and case notes based on them lack the systematicity, not to mention the replicability, usually associated with scientific observation. In the analysts' way of conducting the interview, the agenda of helping and the agenda of generating knowledge are inevitably intertwined. But in dealing with a topic like the current one, hypothetical knowledge as generated in the psychoanalytic interview is relevant: psychoanalysis is a setting where the patient's images of self, and the diffuse emotions associated with them, are addressed and clarified.

Pietari, or "Peter," was a man in his late twenties when he started psychoanalysis. To protect his anonymity, some details of his story have been changed, although the psychological picture is preserved. Peter saw me four times a week for several years. His presenting problem involved sadness, anxiety, and lack of motivation. My notes below come from the first two years of treatment, when problems with his image of self manifested themselves most clearly. In his narratives, he repeatedly went back to events 15 years before: something went wrong when he and his family

\footnotetext{
${ }^{6}$ Should this be the case, then we might think, as Lasch (1979) seemed to propose 35 year ago, that narcissistic personality disorder has become an epidemic in society or, as the critics of medicalization such as Frances (2013) propose, that psychiatric diagnoses such as narcissism involve the pathologization of inherently normal human fragility.
} 
moved to another city when he was around 14 . Since then, he had felt weak, an outsider, shy, and worthless.

In what follows, I present some unedited but translated fragments from my clinical notes during the first two years of analysis. The letters $\mathrm{CN}$ followed by a number refer to the corresponding page in my clinical notes.

Peter repeatedly depicts himself as feeling weak in social interactions. $\mathrm{He}$ tells me that after the family moved and he had to go to a new school, he suddenly started to feel that he was worth nothing. He became thoroughly embarrassed (CN 18). He tells me about sitting in a bar with a group of others the night before: "worried beforehand that shyness and timidity will hit me again — that's what happened — the others conversed in a spontaneous way, I was not able to say anything — feeling that now they see that in reality I am this weakling, being active during lessons has been just showing off (describes his feeling: unbearable anxiety)—closing ritual: I could not participate, I withdrew as if I was sending a text message" (CN 137). In describing another event, he tells me: "Then I tried to talk with people-it was really difficult - had the feeling that I am in no way interesting-I have no right to talk to them" (CN 140). In describing his interactions with an older colleague, he says: "Occasionally I feel that Timo appreciates me-but then again that he treats me as a little child—doesn't take me seriously when talking about male business" (CN 141).

Peter is anxious about not being liked and longs for acceptance. "In conversations, it is as if I were walking on a tightrope. I am afraid that I will not be liked" (CN 13). "I have an endless need to be admired and attended to" (CN 151).

Repeatedly, Peter gets immersed in daydreams of extraordinary success. The strongest dream is to become a famous computer game designer: "this morning: now I have to start (creating storyboards and sketches)—now the dream is stronger than ever-fantasies about recording sessions and launching events-producing the game with Esa's team-what might they think if they knew" (CN 130).

His feelings and thoughts alternate between full immersion in this dream, and doubts and rejection of it, and recognition of the dream as one that arises from his unsatisfied need for acceptance. At a moment of immersion, he can tell me: "watching (a segment of a game that he made)almost passing out—hands becoming numb—so powerful—made by me" (CN 132). And again on a another day: "the computer-game dream: crazy with happiness" (CN 97). In one session, however, he tells me how he showed his sketches to a friend and became worried that the friend might not like the recordings: "whether my enthusiasm in computer-game design was a euphoria and an ego-trip" (CN 131). The immersion into the dream can give way to complete rejection of it: "shyness and blushing-I hate myself. Could kill myself, have no right to live. The dream of being a computer-game 
designer: as I am like this, I realize that I have no rights to that" (CN 127). In a session some days later he is still in doubt: "are these dreams of being a game designer in vain" (CN 127). In some moments, he considers his dream as something that arises from his unsatisfied needs: "I have an endless need to receive admiration and attention - the dream of becoming a computer-game designer is part of that" (CN 151).

Goffman's (1967, p. 8) description of a person being "out of face" captures many of the experiences that Peter relates to me (see also Goffman 1956). In such a situation, an encounter with others does not sustain the image of self that the person wants to present and is emotionally attached to. "A person may be said to be out of face when he participates in a contact with others without having ready a line of the kind participants in such situations are expected to take" (Goffman 1967, p. 8). Such a person, according to Goffman, is "likely to feel ashamed and inferior because of what has happened to the activity on his account and because of what may happen to his reputation as a participant." Such an experience will "momentarily incapacitate him as an interactant" (p. 8).

While Goffman describes the momentary painful experience of being out of face and embarrassed, for Peter, being out of face seems to be an enduring state. He feels that he is enduringly incapacitated as an interactant. He seems to be unable to assume approved social attributes. Instead of a positive self-cathexis, his feelings and thoughts are attached to this inabilitycausing persistent emotional pain. Furthermore, it seems that Peter seeks to cure his damaged face through solitary fantasies of extraordinary success. What is it that does not work?

If we are to believe Goffman's idea of self, Peter is as much dependent on recognition by others as everyone else. The only social face that he could ever have would be "a loan to him from society" (Goffman 1967, p. 10). The encounters that Peter describes in his narratives seem to me, in themselves, not essentially different from what one would expect in an ordinary social encounter. It appears that Peter is not suffering from what Goffman (1963) and many others call stigma: his difficulties do not arise from a publicly observable discrediting attribute, leading to rejection by others. Yet Peter remains with the experience that he is out of face, feeling ashamed and inferior. The problem seems to lie in his inability to receive recognition from others.

In sum, this might be a Goffmanian reading of Peter's problem: he is unable to enter into reciprocal face work, which is the only way available for us to acquire a social face. The problem may have to do with the vulnerability and insecurity (Rawls 1987) that face work brings with it: with face work, you basically have to accept that your image of self is in the hands of others-just as others' self-images are in your hands. As this kind 
of mutual dependence is for some reason unavailable to Peter, what he is left with, instead, are solitary fantasies of strength and independence.

Occasionally in my conversations with Peter, his inability to receive recognition of his projected self is topicalized. In one session, he tells me about classes that he takes at university: "a 65-year-old teacher-likes measks me questions_-'as you have opinions'-feeling that he wants to please me, I have manipulated him to like me" (CN 115). In another session, I ask him about the ways in which ordinary social encounters might or might not give him what he longs for in his daydreams: this is how I describe the exchange in my notes (my utterance is marked with angle brackets): "I have an endless need to receive admiration and attention-the dream of becoming a computer-game designer is part of that $-\ldots<$ is this need in such a way bottomless that the attention and admiration that can be received in ordinary situations is not at all enough, but leaves you empty?>It's rather so that I am not able to get attention and admiration in ordinary situations" (CN 151).

There seem to be two facets in Peter's inability to engage in reciprocal face work. On the one hand, the self that he dreams about (most saliently, being the center of admiration and attention as a computer game designer) is something that copresent others cannot recognize-they do not even know about this dream, let alone share it as common ground. He is left alone and unrecognized with his fantasy. On the other hand, Peter cannot make use of, or even believe in, the recognition that others do offer-for example, in Peter's eyes, the teacher's way of acknowledging his opinions is not genuine but based on his having manipulated the teacher. So Peter does not get from others what he longs for, and what he does get, he is not able to make use of.

Now let us recall how Kohut (1971) describes the development of mature narcissism: the infant's grandiose self-image becomes modified and integrated into the rest of the psychic apparatus with a more realistic conception of the self. In narcissistic disorders, such gradual integration does not take place, but instead, the grandiose fantasies remain, isolated and dissociated from "the reality ego" or "the rest of the psychic apparatus" (Kohut 1971, p. 144). The Goffmanian reading of Peter's problems reveals the social facet of this lack of integration. Peter's inability to receive and make use of recognition from others involves a split, or communicative barrier, between his self-image and the public interactional work that maintains the social self. Thus, while for Kohut, the reality from which the narcissistic self-image is detached involves a psychic structure ("the reality ego"), in a Goffmanian reading, it involves the interactional production of the social self in encounters. Peter's self-image is dissociated from the practices and structures of face work. There is no reason to think that these conceptualizations of the isolation of a narcissistic self-image are mutually exclusive: the isolation 
American Journal of Sociology

of a self-image from a "reality ego" may entail its isolation from face-work practices.

I would like to propose that the story of Peter's treatment shows that Goffman's idea of face and face work is relevant for understanding narcissistic disorders. However, the clinical material also suggests a need for revision or expansion of the concept of face. There are two such issues; both involve the Goffmanian view accommodating some of the perspectives that we ascribed to psychoanalytic views in the preceding section.

First is the historicity of face and face work. For Goffman, face is first and foremost situational. Being out of face, and therefore incapacitated as an interactant, is a momentary experience. Peter's narratives, however, suggest that face has transsituational and autobiographical aspects. Encounters where he felt out of face live in his memory, for years and decades. This suggests that the copresence of encounters has its historicity. It may be that unsuccessful face work remains in our autobiographical memory more than does successful face work.

The second revision that the clinical material suggests for Goffmanian theory involves something that might be called the psychological competence required by face work. Although Goffman occasionally refers to personality differences in people's inclination to experience the vulnerability of their face (1956, pp. 267-68), his main line of argumentation is that problems of face are to be understood in terms of momentary interaction rather than personal maladjustment (pp. 269-70). The psychological view and the interactional view need not be unrelated, however. As Goffman (1967, p. 3) himself emphasized, "psychology is necessarily involved" in the study of interaction, and in light of the difficulties in face work of persons with narcissistic problems (like Peter), it appears that this psychology can and should be elaborated.

Individuals seem to need a certain psychological competence in order to benefit from face work, to be able to receive the recognition of their self that others in interaction can offer them. Peter appears to lack these features. In a most general sense, we are talking about emotional and cognitive dispositions: the ways in which a person, in the copresence of others in a social encounter, is able to recognize and appraise features and properties in herself and in others that embody worthiness of the self. The full explication of these competencies would require the merging of perspectives from self psychology and interactional sociology and is beyond the scope of this article. Below, however, some directions for future research will be suggested.

In the next section of the article, I first revisit the ideas of Donald Winnicott, a British pediatrician and psychoanalyst of the object relations school, whose proposals resonate strongly with the tenor of Goffman's theory. Then I discuss the more recent development of Winnicottian concepts, suggesting 
that playfulness may be one aspect of the psychological competence required for successful face work.

\section{Origins $\backslash$ Restoration of Psychological Competence for Face Work}

In nontechnical language, Winnicott (1971) helps us see the origins of the psychological competence for face work. Winnicott, like Goffman, talks about face but, in a concrete sense, about the mother's (and the other's) face. For him, the mother's face is a mirror in which the baby or the infant first recognizes itself. To put this in Goffmanian terms, Winnicott seems to be suggesting that this is the ontogenetic origin of face and face work: where the infant first establishes herself. Just as in Goffman (and in James, Mead, and Cooley), so also in Winnicott, the self emerges only when the other, in interaction, recognizes it (for a recent reworking of these ideas, see also Honneth [2008]). Thus, Winnicott was able to say that the mother and the family are "giving back to the baby the baby's own self" (1971, p. 6). If difficulties arise in this - and sometimes they do- the individual's experience of self will be problematic. In Goffmanian terms, we would say that the psychic competence necessary for benefiting from face work in later life might not develop under these circumstances.

Winnicott considers psychotherapeutic processes that can be helpful, as a parallel to the original face work between infant and mother. Psychotherapy involves "a long-term giving the patient back what the patient brings. It is a complex derivative of the face that reflects what is there to be seen" (Winnicott 1971, p. 5). If the therapy goes well, "the patient will find his or her own self, and will be able to exist and to feel real" (p. 5). In Goffmanian terms, we might then say that psychotherapy involves a specific institutionally ascribed variant of face work. Recent conversation-analytic research has started to specify the interactional practices through which this work takes place (Peräkylä et al. 2008). Below, I elaborate on some aspects of this work through theoretical discussion, thereby elucidating further the psychological competence required for face work.

Let us return to Peter's fantasy of becoming a famous computer game designer-the fantasy that is, at times, the center of his inner life. How should a therapist relate to such an image of self? For Kernberg (1975), such grandiosity is a result of pathological development. In psychotherapy, it is the task of the therapist to confront the patient with it, so as to show him or her how the fantasy serves as a defense.

On the basis of ideas from Kohut and Winnicott, Stephen Mitchell ([1986] 1999) — a leading proponent of the relational school of American psychoanalysis (see Mitchell 2000)-has formulated a rather different view. In his view, there is no fundamental difference between "normal" 
and "pathological" narcissism. As Kohut (1971) already pointed out, grandiosity, as well as idealization, are necessary illusions in childhood. Grandiosity and idealization in adulthood are, essentially, a continuation of what we see in children: "the core of the self and the deepest source of creativity" (Mitchell 1999, p. 161). However, there are more or less benign, more or less beneficial forms of narcissism. For Mitchell, the subject's relation to his or her illusions is the key question: whether one can playfully maintain them (and give them up) or whether one is claiming a status of reality for them.

Seen from this perspective, Peter's problem is not his self-image as a famous computer game designer in the future but the way in which he rigidly sticks to this illusion, alternating between the feeling that this really is his purpose in life and the feeling of defeat when he suspects that it is not going to work. This rigidness may be a psychological counterpart of the dissociation between his fantasied self-image and the social processes of real interactional face work.

Importantly, for Mitchell, a narcissistic illusion is a way of relating to others. Maintenance of a narcissistic illusion can be a joint activity. "An ability to play together, including a participation in each other's illusions, is a crucial dimension not only of adult-child relationships, but of adultadult relations as well" (Mitchell 1999, p. 170). It appears that this capacity for participatory play is hampered in narcissistic problems.

Empirical infant research elucidates the developmental basis of playful participation in illusions. Pretend play-emerging around the second birthday-is where the playful social self probably first comes about (see, e.g., Bergen 2002). Joint pretend play involves fantasized identities—“I am drinking from this cup," "I am the shopkeeper"- that others are invited to take part in (Tomasello 2008, p. 152). Elaborating the developmental path further, Fonagy and his coworkers (Fonagy and Target 2000; Fonagy et al. 2002, pp. 253-90) suggest that a very young child has two distinctively different modes of representing internal states: the psychic equivalent mode, according to which what is in the mind is also in the outer world, and the pretend mode, according to which the internal reality and the outer reality are unconnected. While a very young child maintains a strong distinction between these modes, in the fourth or fifth year the normally developing child becomes able to integrate them in a "mentalizing mode of psychic reality" (p. 263). The child becomes able to "'know about' his idea or wish, alongside experiencing it" (p. 266), and to play with reality (p. 267). Even with adults, however, the mentalizing capacity can be more or less present in any particular moment (p. 268). It appears that when there, the mentalizing capacity makes possible the benign, playful maintenance of narcissistic illusions.

In sum, I would like to suggest that the capacity for playful participation in one's own and others' illusions, embedded in a more general mentalizing 
capacity, is one part of the psychological competence for face work. Having said this, we should now return to Goffman, asking whether there is room for play and illusion in his theory. The acknowledgment of the importance of play and illusion indeed invites some conceptual and empirical elaboration of Goffman's concepts of face and face work.

Let us start from the conceptual end. In his 1955 essay, Goffman treats face as a sacred object in the Durkheimian sense. The Durkheimian sacred (Durkheim [1912] 2001) is something unconditional and serious. Face, understood as a person's "most personal possession and the centre of his security and pleasure" (Goffman 1967, p. 10), is not playful. The picture, however, becomes more varied in Goffman's later work. In "Frame Analysis" (Goffman 1974, esp., pp. 48-52) and "Response Cries" (Goffman 1978) he discusses playfulness extensively, although he does not directly address questions of self (but rather the transformation of frames of action). A person's relations to his or her self-image becomes a topic in 1961 as Goffman introduces the concept of role distance and its sister concept role embracement (see also Goffman 1974, pp. 269ff.). Role embracement means for the person "to disappear completely to the virtual self available in the situation, to be fully seen in terms of the image, and to confirm expressively one's acceptance of it" (Goffman 1961, p. 102). In role embracement, we are, fully and seriously, our situational selves. Role distance, however, involves that "the individual is actually not denying the role but the virtual self that is implied in the role for all accepting performers" (p. 103). In role distance, we know, and indicate to others, that the situational self is not really what we are. It is of course self-evident that there is a fine gradation between full role embracement and full role distance.

Now, we might ask whether Goffman's and Mitchell's perspectives can meet through the concept of role distance. Would role distance, as a cognitive, emotional, and expressive practice, involve a way for the individual to orient to his or her social self in interaction as an illusion, as part of a Winnicottian playing? The answer may not reside in the exegesis of Goffman, Mitchell, or Winnicott but in observations from interactional practice. Therefore, I would like to return to our starting point, the two sisters Tuula and Jaana in extract 1 (see fig. 1). We will examine their conduct in enacting their social selves, looking for possible indications of playful stance-taking.

Tuula's challenging response (in lines 19-22 and 25) to Jaana's assessment is where questions about the image of self become explicit. Tuula makes a blunt assertion about her own preferences, with a voice and face that are affectively neutral. Her "extreme case" (Pomerantz 1986) lexical choices (lines 19 and 20: "never," "any") as well as her high head position convey determination. In consequence, it is difficult to see any role distancing or playfulness of the self-image here. 
In her next turn in lines 28, 29, and 32, Jaana seems to orient to Tuula's prior utterance as serious. Through a description of her own cooking habits, marked as contrastive to what Tuula has just conveyed, Jaana portrays her hedonistic self. So, as far as the observable interaction goes, both Tuula and Jaana make an effort "to be fully seen in terms of the image" that the momentary interaction projects in their utterances in lines 19-33.

The situation, however, is different during Jaana's assessment regarding the healthiness of honey in lines 13-18. Here she displays role distance, apparently as a way to deal with the anticipated disaffiliation of her interlocutor. This happens very concretely, by her moving from first-person perspective ("in my opinion"; line 13) to epistemically downgraded thirdperson perspective (supposedly/muka olevinaan) in lines 14 and 18. Importantly, her face and posture convey playful apology and appeal (see figs. $2 B$ and $2 C$ ).

So, it appears that Jaana, in lines 13-18, in anticipation of the cointeractant withdrawing support of her claimed self-image, backs away from that virtual self in a playful way. However, when she then assumes a different self (lines 28, 29, and 32), she does so seriously, without any recognizable role distance or playfulness.

Much more observation of interactional practice would be needed, but on the basis of the little that we have seen, it does appear that a person's position vis-à-vis his or her social self can be observed in interaction. Playfulness or seriousness of that positioning can be manifest in overt expression in multimodal ways. ${ }^{7}$ The data that we have at hand also suggest that playfulness and seriousness, or their differing degrees, can change moment by moment, even within a single utterance (cf. Levinson 1988).

This would indeed make sense in the context of psychotherapy. It suggests that patients can and do change their positions regarding their narcissistic illusions, in one moment being more playful and in another being more serious. One of the tasks of the therapist would then be to facilitate and nurture the playful moments, as well as the movement between the serious and the playful. In doing so, the therapist would be cultivating a practice, the home base of which is in everyday interaction.

\section{CONCLUSION}

In this article, I have discussed and elaborated conceptual linkages between Goffman's theory of face and psychoanalytical discussions of normal

\footnotetext{
${ }^{7}$ It should be pointed out that a playful stance toward the projected self, and role distancing, are not equivalent: as Goffman's essay (1961) implies, role distance can be serious, when the actor indicates that he or she genuinely disavows the virtual self that her behavior implies.
} 
and pathological narcissism. With the help of psychoanalytic discussions on narcissism, I have reworked what Goffman (1967) referred to as the psychology that is necessarily involved in the study of interaction. My psychology was perhaps not "stripped and cramped" (Goffman 1967, p. 3) like what Goffman intended his psychology to be: my argument has been that the engagement with more elaborate psychology discussed here can enrich the study of interaction. The argumentation has been mainly theoretical but enhanced by the analysis of fragments of conversational and clinical data.

The theoretical contribution made in the article is threefold. First, I pointed out that there is a link between Goffman's theory of face work and the classical psychoanalytic conceptualizations of narcissism. The link is terminological—both speak about cathexis of self-but also conceptual, as in both strands of thinking, the self is seen as emotionally charged. However, the emergence of the cathexis of the self is seen in different ways: Goffman foregrounding the situational experience, momentary fragility, and anchoring in the structure of interaction, and the psychoanalytic theorists foregrounding biographical experience, durability, and anchoring in the psychic structure.

Second, I suggested that while Goffman's theory of face work is largely indifferent regarding individual differences, let alone individual pathologies, the theory can, if modified, offer conceptual resources for understanding pathological narcissism. Elaborating on a clinical vignette, as well as Kohut's key formulations, I suggested that in pathological narcissism, there is a dissociation between a person's self-image and the interactional practices of face work. While in persons with normal narcissism, the self-images arise from, and are offered for, acknowledgment in the interactional process of face work, in pathological narcissism, they are split away from that. This split or dissociation amounts to an inability to receive and make use of recognition from copresent others and results in grandiose and vulnerable self-states. Observations on pathological narcissism, however, call for a revision in Goffman's theory: I suggested that there is a cross-situational continuity in face work, and there are specific psychological competencies, not equally shared between all individuals, that successful face work builds on.

Third, I suggested that playfulness in relation to self-images is one key part of the psychic competence required for successful face work. Such playfulness is an aspect of what in more recent developmental psychological research has been called mentalizing, and it has its ontogenic origins that have been explored in recent research. While Goffman's notion of role distance may be useful in tracing practices of playfulness in social interaction and face work, it is empirical work with conversational materials that is primarily needed for enhancing our understanding regarding ways in which persons can variate their momentary relation to the selves that 
they assume, and offer for social acknowledgment, in social interaction. On the basis of conversation analysis of a fragment of speech, I suggested that all modalities of expression can be involved.

In the article that became his intellectual testament, Goffman (1983, p. 3) pointed out that there is an "inevitable psychobiological element" in the interaction order. Undoubtedly, Goffman would have included the emotions attached to face in this inevitable psychobiology. This article took up the psychoanalytic and psychiatric theories of narcissism to elaborate on that aspect of psychobiology of the interaction order. While doing so, the article pointed out actual and potential linkages between the Goffmanian and the psychoanalytic traditions.

It is not self-evident that showing linkages between two or more traditions is useful for furthering knowledge. It does not add much to our knowledge to demonstrate that what is called, say, $\mathrm{A}$ in one tradition might quite well be called B if we take another tradition as our point of departure. Things can indeed be labeled with different names. However, the demonstration of linkages between different traditions may be genuinely useful if it leads to an enrichment of the concepts and ideas of the tradition in question: if the linking of traditions leads to a new understanding of what is called $\mathrm{A}$ in one tradition and $\mathrm{B}$ in another.

I would like to suggest that we have indeed gained a new understanding regarding what Goffman calls face and what psychoanalysts call narcissism. In relation to the psychoanalytic tradition, we can suggest at least the following items: (1) Even if the self and its cathexis involve intrapsychic structures, it is in the context of situated social interaction that they are manifested and modified. (2) Even with typically developed healthy individuals, self-cathexis is inherently fragile. Rather than a stable self-image, healthy narcissism involves tolerating inevitable moments of insecurity for the self in interaction. (3) The grandiose self-image of persons with narcissistic problems is dissociated not only from the more reality-oriented areas of the mind but also from the interactional processes of self-maintenance. (4) A person's relation to his or her narcissistic illusions is manifested and displayed in his or her interactions with others and, in healthy interactants, is subject to moment-by-moment change.

In relation to the Goffmanian concept of face, we can suggest the following items: (1) Being able to maintain a satisfactory social face in interaction presupposes psychological competences that not all persons share. (2) The interactional maintenance of the self and its cathexis has a transsituational dimension: what is achieved or perhaps especially what is not achieved in face work remains in autobiographical memory and tends to be repeated. (3) Face-work practices, as well as the psychological competences they are based on, have their ontogenic origins in infant-caretaker interaction and in joint pretend play. (4) Social selves and faces in interaction 
can involve different degrees of playfulness and illusion, displayed on a moment-by-moment basis by the participants.

As these suggestions arise from considerations that are mostly theoretical, they are hypothetical and should be subjected to empirical validation. Typically developed subjects as well as subjects with diagnosed narcissistic personality disorders should be involved in such research. Observational methods of the study of interaction should be combined with methods geared to tracing the self-experience of the participants in interaction. In tracing these self-experiences, both momentary and autobiographical timescales should be included.

\section{APPENDIX}

TABLE A1

Conversation Analytical Transcription Symbols

\begin{tabular}{|c|c|}
\hline Representation & Description \\
\hline${ }^{\circ}$ word ${ }^{\circ}$ & Segment quieter than the surrounding talk \\
\hline \#word\# & Creaky voice \\
\hline word & Emphasis \\
\hline $\begin{array}{c}\text { wo [rd wo }] \mathrm{rd} \\
\text { [word] }\end{array}$ & Onset and end of overlapping talk \\
\hline @word@ & Animated voice \\
\hline$£$ word $£$ & Smiley voice \\
\hline wo:rd & Stretched sound \\
\hline hhh & Outbreath (length indicated by the number of h's) \\
\hline .hhh & Inbreath (length indicated by the number of h's) \\
\hline $\mathrm{w}(\mathrm{h})$ ord & Laugh particle inserted in the talk \\
\hline word. & Falling intonation at the end of a segment of talk \\
\hline word? & Rising intonation at the end of a segment of talk \\
\hline word, & Level intonation at the end of a segment of talk \\
\hline$>$ word $<$ & Speech faster than the surrounding talk \\
\hline$\downarrow$ word & Fall in pitch \\
\hline$(0.4)$ & Silence (in seconds) \\
\hline (.) & Micropause (shorter than 20 milliseconds) \\
\hline
\end{tabular}

Note.-For more on CA symbols, see Atkinson and Heritage (1984)

\section{REFERENCES}

Akhtar, Salman. 1989. "Narcissistic Personality Disorder: Descriptive Features and Differential Diagnosis." Psychiatric Clinic of North America 2:505-30.

APA (American Psychiatric Association). 2013. Diagnostic and Statistical Manual of Mental Disorders, 5th ed. Washington, D.C.: American Psychiatric Association.

Atkinson, J. Maxwell, and John Heritage. 1984. Transcript Notation, edited by J. M. Maxwell and J. Heritage. Cambridge: Cambridge University Press.

Bergen, Doris. 2002. "The Role of Pretend Play in Children's Cognitive Development." Early Childhood Research and Practice 4 (1). http://ecrp.uiuc.edu/v4n1/index.html.

Brown, Penelope, and Stephen C. Levinson. 1987. Politeness: Some Universals in Language Usage. Cambridge: Cambridge University Press. 


\section{American Journal of Sociology}

Cooley, Charles Horton. 1902. Human Nature and the Social Order. New York: Scribner.

Durkheim, Émile. (1912) 2001. The Elementary Forms of Religious Life. Translated by Carol Cosman. New York: Oxford University Press.

Erikson, Erik H. 1968. Identity, Youth and Crisis. New York: Norton.

Etchegoyen, R. Horacio. 1985. "Identification and Its Vicissitudes." International Journal of Psychoanalysis 66 (1): 3-18.

Fonagy, Peter, György Gergely, Elliot L. Jurist, and Mary Target. 2002. Affect Regulation, Mentalization, and the Development of the Self. New York: Other Press.

Fonagy, Peter, and Mary Target. 2000. "Playing with Reality III: The Persistence of Dual Psychic Reality in Borderline Patients." International Journal of Psychoanalysis 81 (5): 853-73.

Frances, Allan. 2013. Saving Normal: An Insider's Revolt against Put-of-Control Psychiatric Diagnosis, DSM-5, Big Pharma, and the Medicalization of Everyday Life. New York: HarperCollins.

Freud, Sigmund. (1914) 1957. "On Narcissism: An Introduction” [Zur Einführung des Narzißmus]. Pp. 67-104 in The Standard Edition of the Complete Psychological Works of Sigmund Freud, vol. 14. Translated by James Strachey. London: Hogarth. . (1915) 1957. "The Unconscious" [Das Unbewusste]. Pp. 159-204 in The Standard Edition of the Complete Psychological Works of Sigmund Freud, vol. 14. Translated by James Strachey. London: Hogarth.

Gabbard, Glen O. 1989. "Two Subtypes of Narcissistic Personality Disorder.” Bulletin of the Menninger Clinic 53:527-32.

Garfinkel, Harold. 1967. Studies in Ethnomethodology. Englewood Cliffs, N.J.: PrenticeHall.

Goffman, Erving. (1955) 1967. "On Face Work: An Analysis of Ritual Elements in Social Interaction." Pp. 5-45 in Interaction Ritual: Essays on Face-to-Face Behavior by Erving Goffman. Garden City, N.Y.: Doubleday.

- 1956. "Embarrassment and Social Organization." American Journal of Sociology 62 (3): 264-71.

. 1961. "Role Distance." Pp. 85-132 in Encounters: Two Studies in the Sociology of Interaction. Indianapolis: Bobbs-Merrill.

- 1963. Stigma: Notes on the Management of a Spoiled Identity. Englewood Cliffs, N.J.: Prentice-Hall.

-1967. Interaction Ritual. New York: Anchor.

1974. Frame Analysis: An Essay on the Organization of Experience. Cambridge, Mass.: Harvard University Press.

1978. "Response Cries.” Lanquage 54 (4): 787-815.

1983. "The Interaction Order: American Sociological Association, 1982 Presidential Address." American Sociological Review 48 (1): 1-17.

Goodwin, Marjorie Harkness. 1980. "Processes of Mutual Monitoring Implicated in the Production of Description Sequences.” Sociological Inquirv 50 (3-4): 303-17.

Green, André. 2002. "A Dual Conception of Narcissism: Positive and Negative Organizations." Psychoanalytic Quarterly 71:631-49.

Hartmann, Heinz. (1950) 1964. "Comments on the Psychoanalytic Theory of the Ego." Pp. 113-41 in Essays on Ego Psychology: Selected Problems in Psychoanalytic Theory by Heinz Hartmann. New York: International Universities Press.

Heritage, John, and Geoffrey Raymond. 2005. "The Terms of Agreement: Indexing Epistemic Authority and Subordination in Talk-in-Interaction." Social Psychology Ouarterly 68:15-38.

Honneth, Axel. 2008. Reification: A New Look at an Old Idea. Berkeley Tanner Lectures. Oxford: Oxford University Press.

James, William. 1891. Principles of Psychology, vol. 1. London: Macmillan. 


\section{From Narcissism to Face Work}

Joas, Hans. 1985. George Herbert Mead: A Contemporary Re-examination of His Thought. Cambridge, Mass.: MIT Press.

Kernberg, Otto. 1975. Borderline Conditions and Pathological Narcissism. Lanham, Md.: Rowman \& Littlefield.

1991. "A Contemporary Reading of 'On Narcissism.'” Pp. 131-48 in Freud's "On Narcissism: An Introduction," edited by Joseph Sandler, Ethel Spector Person, and Peter Fonagy. New Haven, Conn.: Yale University Press.

2010. "Narcissistic Personality Disorder." Pp. 257-89 in Psychodynamic Psychotherapy for Personality Disorders: A Clinical Handbook, edited by John F. Clarkin, Peter Fonagy, and Glen O. Gabbard. Arlington, Va.: American Psychiatric Publishing.

Kohut, Heinz. 1971. The Analysis of the Self: A Systematic Approach to the Psychoanalytic Treatment of Narcissistic Personality Disorders. Chicago: University of Chicago Press.

Kvale, Steinar. 1999. "The Psychoanalytic Interview as Qualitative Research.” Qualitative Inquirv 5 (1): 87-113.

-. 2003. "The Psychoanalytical Interview as Inspiration for Qualitative Research." Pp. 275-97 in Qualitative Research in Psychology: Expanding Perspectives in Methodology and Design, edited by Paul M. Camic, Jean Rhodes. and Lucy Yardley. Washington, D.C.: American Psychological Association.

Lasch, Christopher. 1979. The Culture of Narcissism: American Life in an Age of Diminishing Expectations. New York: Norton.

Lerner, Gene H. 1996. "Finding 'Face' in the Preference Structures of Talk-inInteraction." Social Psvchology Ouarterlv 59:303-21.

Leudar, Ivan, and Philip Thomas. 2000. Voices of Reason, Voices of Insanity: Studies of Verbal Hallucinations. London: Routledge.

Levinson, Stephen C. 1988. "Putting Linguistics on a Proper Footing: Explorations in Goffman's Participation Framework.” Pp. 161-227 in Evving Goffman: Exploring the Interaction Order, edited by Paul Drew and Anthony Wootton. Oxford: Polity Press.

Maynard, Douglas W., and Don H. Zimmerman. 1984. "Topical Talk, Ritual, and the Organization of Social Relationships." Social Psvchologv Ouarterlv 47:301-16.

Mead, George H. 1934. Mind, Self and Society from the Standpoint of a Social Behaviorist. Edited by Charles W. Morris. Chicago: University of Chicago Press.

Mitchell, Stephen A. (1986) 1999. "The Wings of Icarus: Illusion and the Problem of Narcissism." Pp. 155-77 in Relational Psychoanalysis: The Emergence of a Tradition, edited by Stephen A. Mitchell and Lewis Aron. Hillsdale, N.J.: Analytic.

Analytic.

Ornstein, Paul H. 1991. "From Narcisssism to Ego Psychology to Self Psychology." Pp. 175-94 in Freud's "On Narcissism: An Introduction," edited by Joseph Sandler, Ethel Spector Person, and Peter Fonagy. New Haven, Conn.: Yale University Press.

Parsons, Talcott. 1951. The Social System. Glencoe, Ill.: Free Press.

Parsons, Talcott, and Edward A. Shils. 1951. Towards a General Theory of Action: Theoretical Foundations for the Social Sciences. Cambridge, Mass.: Harvard University Press.

Peräkylä, Anssi, Charles Antaki, Sanna Vehviläinen, and Ivan Leudar, eds. 2008. Conversation Analysis and Psychotherapy. Cambridge: Cambridge University Press.

Pincus, Aaron L., and Michael J. Roche. 2011. "Narcissistic Grandiosity and Narcissistic Vulnerability." Pp. 31-40 in The Handbook of Narcissism and Narcissistic Personality Disorder, edited by W. Keith Campbell and Joshua D. Miller. Hoboken, N.J.: Wiley.

Pomeranz, Anita. 1986. "Extreme Case Formulations: A Way of Legitimizing Claims." Human Studies 9:219-29. 


\section{American Journal of Sociology}

Rawls, Anne. 1987. "The Interaction Order Sui Generis: Goffman's Contribution to Social Theory." Sociological Theory 5:136-49.

Ronningstam, Elsa. 2012. "Narcissistic Personality Disorder: The Diagnostic Process." Pp. 527-48 in The Oxford Handbook of Personality Disorders, edited by Thomas A. Widinger. Oxford: Oxford University Press.

Rosenfeld, Herbert. 1987. Impasse and Interpretation. London: Tavistock.

Schegloff, Emanuel A. 1988. "Goffman and the Analysis of Conversation." Pp. 89-135 in Erving Goffman: Exploring the Interaction Order, edited by Paul Drew and Anthony Wootton. Cambridge: Polity.

. 1996. "Turn Organization: One Intersection of Grammar and Interaction." Pp. 52-133 in Interaction and Grammar, edited by Elinor Ochs, Emanuel A. Schegloff, and Sandra A. Thompson. Cambridge: Cambridge University Press.

Sidnell, Jack. 2012. "Basic Conversation Analytic Methods." Pp. 77-100 in The Handbook of Conversation Analysis, edited by Jack Sidnell and Tanya Stivers. Chichester: Wiley-Blackwell.

Stern, Daniel N., Louis W. Sander, Jeremy P. Nahum, Alexandra M. Harrison et al. 1998. "Non-interpretive Mechanisms in Psychoanalytic Therapy: The 'Something More' than Interpretation; the Process of Change Study Group." International Journal of Psychoanalysis 79:903-21.

Stolorow, Robert D. 1975. "Toward a Functional Definition of Narcissism." International Journal of Psychoanalysis 56 (2): 179-85.

Tomasello, Michael. 2008. Origins of Human Communication. Cambridge, Mass: MIT Press.

Wink, Paul. 1991. "Two Faces of Narcissism." Journal of Personality and Social Psvchology 61:590-97.

Winnicott, Donald W. 1971. Playing and Reality. London: Tavistock. 